Seloka: Jurnal Pendidikan Bahasa dan Sastra Indonesia
$9(3)(2020): 221-229$
UNNES
https://journal.unnes.ac.id/sju/index.php/seloka

\title{
The Influence of Learning Models to Students' Writing Skill of The Explanation Text in Viii Grade at Junior High School (SMP)
}

\author{
Nur Maya Widiyanti ${ }^{1 凶}$, Wagiran Wagiran ${ }^{2}$, Rahayu Pristiwati $^{2}$ \\ ${ }^{1}$ SMP Negeri 22 Semarang, Jawa Tengah, Indonesia \\ ${ }^{2}$ Universitas Negeri Semarang, Indonesia
}

\begin{tabular}{l} 
Article Info \\
\hline History Articles \\
Received: \\
September 2019 \\
Accepted: \\
Oktober 2019 \\
Published: \\
31 December 2020 \\
\hline Keywords: \\
The result of writing \\
skill, learning models, \\
explanation text
\end{tabular}

\begin{abstract}
Learning model is standardization for developing the one's skill and in the interpersonal situations. This study aims to determine the effect of learning models to the test results of the students' writing skill of the explanation text in class VIII grade at junior high school. This research is an ex-post-facto research. The population of this research is all students of VIII grade at SMP of the 2019/2020 academic year. The sample in this study were students of class VIIIA and VIIIB SMP N 22 Semarang with the amount of 64 students who were taken by cluster random sampling, namely by choosing two classes randomly. Data collection techniques were questionnaires for student learning model data and tests to obtain data on the results of the skill to write explanation text for class VIIIA and VIIIB students. The results showed that (1) students with auditory learning models had the highest average score rather than the others who use visual and other learning models. (2) the learning model in this study has a significant effect on the results of the students; skill to write explanation text. (3) The learning model in this study gives e a large effective contribution $89.9 \%$ to the results of the students' writing skill of explanation text; this proved that the learning model is one of the important factors for the students' achievement in writing skill of explanation text.
\end{abstract}

\footnotetext{
$\bowtie$ Correspondence address:

J1. Raya Manyaran-Gunungpati, Nongkosawit, Kec. Gn. Pati, Kota

Semarang, Jawa Tengah 50225.

p-ISSN 2301-6744

E-mail: nmayawidiyanti@gmail.com

e-ISSN 2502-4493
} 


\section{INTRODUCTION}

Learning model is an indispensable component when a learning activity is conducted. Each student has a different background, level of cognitive, meta-cognitive, habits, and motivation. De Porter (2000) states that learning model is standardization for developing the one's skill in interpersonal situations. Learning model is an approach that describes how individuals learn or how each person focuses on the process and attain the difficult and new information through different perceptions (Ghufron \& Risnawita, 2014). Not only by using media, but by knowing the learning models of students, they are able to find ways to make learning easy and fun (Kusnida, 2015). Therefore, if the teacher knows the learning models possessed by students, so they will be able to provide a supportive circle and make it easier for students to absorb information optimally. In addition, students can learn and get good learning results when they understand their learning model. This makes it easier for students to apply learning model easily, precisely, and to improve intelligence skill (Kolb, 1984).

The cognition of the characteristics of students is important in the stage of planning the learning process. Knowing the learning model can influence students to understand knowledge and be able to communicate according to their own model with other individuals. The benefits that are obtained when knowing the learning models of students is helping students by conveying information that is approaching, helping to design classrooms according to the their needs, increasing interaction between students and educators and easier to match learning models with its learning process.

Learning models are classified into three groups according to De Porter, Reardon, and Nourie (2014), namely visual, auditory, and kinesthetic (VAC). Visual learning model focuses on the power of vision. Visual learning models have concrete signs that must be shown first so that students with visual learning models understand. This learning model uses vision to see shapes or situations and it can then capture the information provided. There are several characteristics that are unique for students who have a visual learning model: namely seeing something (information / lesson) visually to find out or understand it, having a strong sensitivity to color, having sufficient understanding of artistic problems, having difficulty in direct dialogue, overly reactive to sounds, difficult to follow verbal recommendations, and often misinterpret a word or speech. Kurniawan's research (2017) states that the use of appropriate learning techniques for individuals with visual learning models, namely using colors and images in text, using system diagrams to visualize the relationship between parts of a system, visual form demonstrations and story techniques to make it easier to memorize material abstract.

Auditory learning model uses hearing to understand and remember. Auditory learning model characteristics place hearing as the main sensory tool for understanding the information or knowledge provided. Auditory learning model individuals must listen, and then they can remember and understand the information. There are several unique characteristics for students who have an auditory learning model; they tend to understand information through hearing, have difficulty absorbing information in written form directly, and have difficulty writing or reading. The typical words used by people with an auditory learning model in conversation are not far from the expression "I heard what you said" and the speed of speech is moderate. Kurniawan (2017) states that the right learning techniques for individuals with auditory learning models, namely using sound, rhymes, and music in learning activities, using sound recordings to help visualize the information provided, applying mnemonic learning techniques (donkey bridges) involving rhythm so it's like making a jingle or song piece. In addition, students with auditory learning models are advised to touch something in providing certain information so that they can remember it. Of course, there are characteristics of this learning model that not all individuals have. Kurniawan's research (2017) 
states that students with an auditory learning model do not like to sit still for too long in a place. These students will prefer to be directly involved in / directly involved with the problem / topic at hand rather than having to read or look at diagrams first.

There are several previous studies state that educators must understand the learning models of students in the learning process. Gilakjani (2012) states that learning models can help students more focus and attentive so that it has an impact on the success of learning goals. Then, Widayanti's research (2013) states that observation and research on student learning models are needed by educators (teachers, lecturers, instructors, tutors) to design learning models, approaches, strategies and methods. Moussa's research (2014) states that learning models can help in improve the quality of learning activities as well as an effective learning environment by developing teaching methods that incorporate various learning models.

One of the most important uses of learning models is that it can make it easier for teachers to align learning models, media, models, and learning strategies into learning activities to achieve optimal learning goals. One of the learning objectives that must be taken optimally is writing explanation text. Writing explanation text contained in KD 4.10 presents information and data in the form of explanation text on the process of a phenomenon orally and in writing with attention to structure, linguistic elements, or oral aspects. Gebhardt and Dawn Rodrigues (1989) state that writing is one of the most important things that to do in school. Writing helps in developing the skill to concentrate, understand meanings, and distinguish codes, associations, and feelings. Writing skills must be in line with reading skills. In addition, the benefits of developing writing skills to stimulate children to learn to write, the brain's natural learning system can be effective and all the potential of a learning person will be explored and awakened (Olivia, 2013).

Text is a language unit that is expressed in writing and meaningfully with a certain organizational structure that functions to express ideas, then it is given in the form of written works (Afandi, and Zulaeha, 2017). Meanwhile, explanation text is a text that explains the process of natural and social phenomena (Kosasih, 2014). Knapp, Watkins (2005) said that explanation text has two main orientations to explain why and explain how. Both of these explanations will appear in a complex explanation text. The benefit of writing explanation text is to train creativity in looking for material to be studied from various phenomena and natural disasters that have occurred around us. There are five main aspects in the criteria for composing an explanation text which are used as the basis for assessment, namely (1) suitability of the text content, (2) accuracy of text structure, (3) vocabulary, (4) use of language, and (5) mechanics (Kemendikbud, 2013: 79-81). The scoring model with these rubrics is proportional based on the weight of the components to be assessed. The number of weights for each component is different because each component has its own difficulty level. The content component has the highest weight because this component involves a number of sub-categories that are difficult to fulfill in the writing process.

Since the implementation of the 2013 Curriculum, the learning process of writing explanation text is still theoretical. There are still many learning to write explanation text carried out by the teacher in the form of theories and applying the one method only. This is in line with the results of observations made by Krisbiono (2015) which states that the learning process of writing is still theoretical so far, emphasizing the aspects of knowledge and understanding only, teachers in using the learning model are still not optimal, while the practical aspects have not received the attention of the teacher. In fact, if the teacher pays attention to the learning models of students, students who have auditory learning models and visual learning models can get optimal results of the skill to write explanation text. In line with this, Hakim (2018: p. 261) conducted a research entitled Learning Writing Explanation Text Using Group Investigation Models Based on 
Learning Model. Judge (2018) stated that learning to write explanation text must be supported by an analysis of the learning models of each participant. Due to that, the educators can design learning strategies that are easy to understand, comfortable and fun for students according to their learning models. Based on the description above, it can be seen that each student is influenced by the learning model of the skill to write explanation text. Therefore, the aim of this study was to analyze and examine the effect of learning models on the results of the skill to write explanation text.

\section{METHOD}

This study was carried out at SMP N 22 Semarang in the odd semester of the 2019/2020 academic year. This study is an expo-facto research because the independent variables are not controlled or these variables have occurred. The population in this study is all class VIII students. The sample used was class VIIIA and VIIIB, the amount is 64 students. The sampling technique used was cluster random sampling. Cluster random sampling is a method of taking sampling based on a group of individuals and not taken individually or individually (Azwar, 2011: 87). This study consisted of two variables, namely the dependent variable (interval scale), namely the result of the skill to write explanation text (X) and the independent variable (independent) on the interval scale, namely learning model (Y). The data collection technique uses a questionnaire method for student learning model data and test techniques for data on the results of the skill to write explanation text. The data analysis of this study used linear regression analysis. As a requirement for data analysis, a normality test was carried out using the Kolmogorov-Smirnov method and the linearity test.

\section{RESULTS AND DISCUSSION}

The result of this study are the result of the questionnaire about learning models and the effect of learning models to students' writing skill of explanation text in VIII grade at Junior High School.

\section{The Result of Questionnaire About Learning Models}

There are several indicators to distinguish between students with auditory learning models and students with visual models. Auditory learning model students have several criteria: (1) more quickly absorb information by listening; (2) enjoy reading aloud and listening; (3) good at speaking and telling stories; (4) remembering what was discussed rather than seen, and (5) are good at spelling out loud rather than writing them. On the other side, the visual learning model students have the following characteristics. They are (1) easy to remember what they see; (2) like to scribble something that is sometimes meaningless in class; (3) more like reading rather than being read; (4) understands pictures and charts better than written instructions; and (5) knows what to say, but doesn't think of the right words.

The learning models questionnaire consists of 10 questions for each learning model. These questions come from indicators of each learning model. The details of students' learning models in diagram 1 show that students tend to have several criteria. They like to remember what they see; moving lips and say the writing in a book when reading; like to be read, neat and orderly, remember what is discussed rather than seen, be thorough to detail, understands pictures and charts better than written instructions, likes music and singing, can't stay still for long, and likes to do work in groups. This is an indicator contained in the auditory learning models. The number of students with details of learning models as follows. 


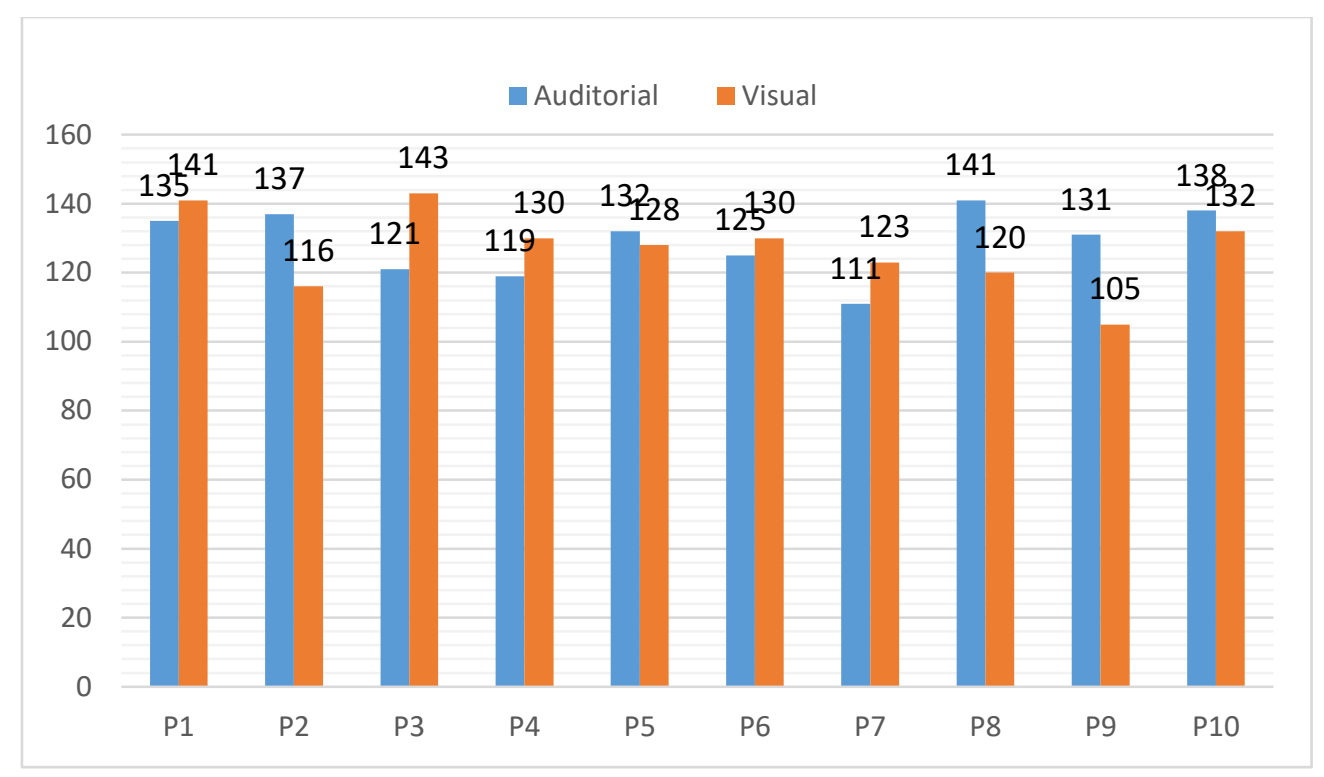

Diagram 1.Students' Learning Models

Note: P1. P2. P3 .. P10 = Ouestion 1. Ouestion 2. etc

Table 1.The Classification of Learning Model

\begin{tabular}{|l|l|l|l|}
\hline No. & Leaning Model & Percentage & Amount \\
\hline 1 & Auditorial & $43.75 \%$ & 28 \\
\hline 2 & Visual & $39.06 \%$ & 25 \\
\hline 3 & Lainnya & 17.18 & 11 \\
\hline Jumlah & $100 \%$ & 64 \\
\hline
\end{tabular}

Table 2. The Result of Learning Model of Each Student in a Group

\begin{tabular}{|l|l|l|l|l|l|l|l|}
\hline No. & $\begin{array}{l}\text { Learning } \\
\text { Model }\end{array}$ & Range & Min. & Max. & Mean & $\begin{array}{l}\text { Dev. } \\
\text { Standar }\end{array}$ & Variation \\
\hline 1 & Auditorial & 28 & 54 & 82 & 69.85 & 8.333 & 69.439 \\
\hline 2 & Visual & 31 & 48 & 79 & 64.00 & 9.065 & 82.167 \\
\hline 3 & Lainnya & 29 & 53 & 82 & 64.17 & 8.233 & 67.788 \\
\hline
\end{tabular}

Based on table 1, it can be seen that there are 64 students with a tendency to auditory learning models as many as 28 students (43.75\%), 25 students (39.06\%) in visual learning models, and 11 other learning models tendencies (17.18\%).

Then, it can be seen from table 2 that the average grouping of student learning outcomes based on the tendency of their learning models that students with auditory learning models have the highest average value compared to the tendencies of visual or other learning models. Furthermore, the table also provides information about the range of data, smallest data, largest data, mean, standard deviation and variance for learning outcomes, auditory learning models, visual learning models, and other learning models.

\section{The Result of Pre-requisite Test}


Table 2.Normality Test

\begin{tabular}{|ll|}
\hline Kolmogorov-Smirnov $^{\mathrm{a}}$ & \\
Variabel & Sig. \\
Gaya_Auditorial & $.200^{*}$ \\
Gaya_Visual & $.200^{*}$ \\
Hasil_Siswa_Menulis & $.210^{*}$ \\
\hline
\end{tabular}

Tabel 3. Ringkasan Uji Linearitas

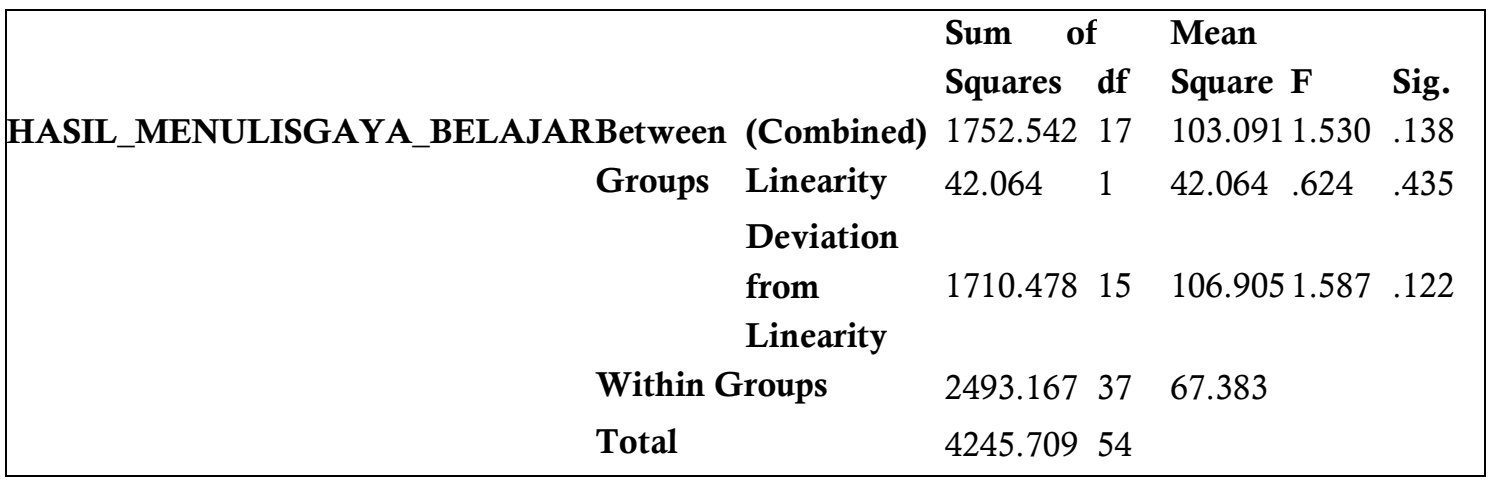

The pre-requisite test results before carrying out the linear regression test, namely the normality test. Based on prerequisite testing, the calculation results of the normality test using the Kolmogorov Smirnov test method with a significance value of more than 0.05 .

Based on table 2, the One Sample Kolmogoof-Smirnof Test normality test obtained a variable significance value of $0.200>0.005$, so it can be concluded that the sample data from each variable comes from a normally distributed population.

The linearity test is used to determine whether the relationship between each independent and dependent variable in the study is linear or not. The data is said to be linear if the significance value is $>0.05$. The summary of the linearity test is as follows.

The summary of the linearity test in table 3 shows that the significance value obtained is $0.122>0.05$. So it can be concluded that there is a significant linear relationship between the variable results of the skill to write explanation text $(\mathrm{X})$ and the learning model variable (Y). Meanwhile, it is known that Fcount: 0.897 and Ftable: (df deviation from linearity; df Within Groups) or $(15 ; 37)=1.95$. So, Fcount $1.587<$ FTabel 1.95, which means that there is a linear relationship between the independent variable and the dependent variable.

The fulfillment of the normality test and the linearity test can be concluded that the prerequisites for linear regression analysis have been met, then the data can be tested. The results of linear regression analysis are in the following table.

\section{The Result of Linearity Regression Test}

Based on table 4, the constant number of Un-standardized Coefficients is 75,704 . This number is a constant number which means if there is no learning model $(\mathrm{Y})$, the consistent value of the results of the students' explanation text writing skill (X) is 75,704 . Then the regression coefficient value is $-5,852$, this figure means that every $1 \%$ addition of the learning model level (Y), the student's skill to write essay text $(\mathrm{X})$ will increase by $-5,852$. Since the regression coefficient is minus (-), it can be said that learning model $(\mathrm{Y})$ has a negative effect on the results of the skill to write explanation text (X). Based on this description, it can be concluded that the regression equation is $\mathrm{X}=$ $75.704-5,852 \mathrm{Y}$. This negative effect will mean that the closer to the student's learning model it 
will affect the increase in the results of the students' explanation text writing skill.

The test for the mean of the linear regression coefficient for the learning model variable obtained Thit $>\mathrm{T}$ table, namely $2.426>$ 2.052 , so it can be concluded that the learning model variable has a significant effect on the results of the skill to write explanation text. The results of this study are supported by research conducted by Moussa (2014: 25) which states that learning models can be understood as techniques that students choose to understand, process information and interact with the learning environment. In addition, it can identify various dimensions of learning models to be understood by educators with a greater awareness of the unique characteristics of learners. Educators can use this awareness to maximize student learning and support effective education by developing teaching methods that incorporate a variety of learning models.

Related with table 5 , the test results show that the $\mathrm{R}$ Square value is 0.899 . This value means that the effect of learning model $(\mathrm{Y})$ on the results of students 'explanation text writing skill $(\mathrm{X})$ is $89.9 \%$, while $10.1 \%$ of the students' explanation text writing skill is influenced by other variables that are not studied. The learning model in this study gave a large effective contribution of $89.9 \%$ to the results of the students 'explanation text writing skill, this proved that the learning model was an important factor for the achievement of the students' explanation text writing skill. Therefore, in learning activities, students must be directed and helped to identify learning models that suit themselves so that the material they catch can be optimal (Bire, et al., 2014, pp. 168-174). This is in line with the results of research which conducted by Endah (2014) which states that teachers should be able to understand the learning models of students. Understanding learning models for students can be done by giving several small tests to students through the media of images and sounds. Students with different characteristics, the treatment given during the learning process is also different. There are students who easily receive learning material through the sense of hearing (auditory model) and there are students who easily accept learning material through the sense of sight (visual style).

Table 4. The Regression Linear Test

\begin{tabular}{|c|c|c|c|c|c|}
\hline \multirow[b]{2}{*}{ Model } & \multicolumn{2}{|c|}{ Unstandardized Coefficients } & \multicolumn{3}{|l|}{$\begin{array}{l}\text { Standardized } \\
\text { Coefficients }\end{array}$} \\
\hline & B & Std. Error & Beta & $\mathrm{t}$ & Sig. \\
\hline 1 (Constant) & 75.704 & 3.770 & & 20.080 & .000 \\
\hline Gaya_belajar & -5.852 & 2.412 & -.324 & 2.426 & .019 \\
\hline
\end{tabular}

Table 5.The Effect of Variable $Y$ to $X$

\begin{tabular}{|lllll|}
\hline & & & \\
Model & $\mathrm{R}$ & R Square & Adjusted R Square & Std. Error of the Estimate \\
1 & $.298^{\mathrm{a}}$ & .899 & .071 & 9.702 \\
& a. Predictors: (Constant), GAYA_BELAJAR & \\
\end{tabular}

\section{CONCLUSION}

Based on the results and discussion, the following conclusions can be written: (1) student learning outcomes are based on the tendency of their learning models that students with auditory learning models have the highest average value compared to visual and other learning models. (2)there is a significant linear relationship between the variable results of the skill to write 
explanation text $(\mathrm{X})$ and the learning model variable $(\mathrm{Y})$. (3) the learning model variable has a significant effect on the results of the skill to write explanation text. (4) the influence of the learning model $(\mathrm{Y})$ on the results of the students 'explanation text writing skill (X) was $89.9 \%$, while $10.1 \%$ of the students' explanation text writing skill was influenced by other variables which were not studied

\section{REFERENCES}

Afandi, M.I, \& Zulaeha, I. (2017). Keefektifan Buku Pengayaan Menulis Teks Hasil Observasi Bermuatan Multikultural Berbasis Proyek Baca Tulis untuk Peserta Didik SMP. Seloka: Jurnal Pendidikan Bahasa Dan Sastra Indonesi, 6 (2), 187199.

Azwar, S. (2011). Metode Penelitian. Yogyakarta: Pustaka Pelajar.

Bire,Arylien Ludji, Uda Geradus, dan Josua Bire. 2014. Pengaruh Gaya Belajar Visual, Auditorial, dan Kinestetik Terhadap Prestasi Belajar Siswa. Jurnal Kependidikan, Vol.44 November, hal. 168-174.

Bobby de Porter dan Micke Hernacki. 2000. Quantum Learning Membiasakan Belajar Nyaman dan menyenangkan. Bandung: Kaifa.

Cassidy, S., \& Eachus, P. (2000).Learning Style, Academic Belief Systems, Self-Report Student Proficiency And Academic Achievement In Higher Education. Educational Psychology, 20, 307-322.

Endah, Wiwik Kus. (2014). Perbandingan Pembelajaran Membaca Permulaan dengan Menggunakan Metode Sas dan Metode Kata Lembaga Berdasarkan Perbedaan Gaya Belajar pada Peserta Didik Taman Kanak-Kanak. Jurnal Seloka: Jurnal Pendidikan Bahasa dan Sastra Indonesia Volume 3 (2) ISSN 2301-6744.

Gebhardt dan Dawn Rodrigues. 1989, The Cambridge Encyclopedia of Language. Cambridge: Cambridge University Press.
Ghufron, M \& Risnawati, Rini.(2012). Gaya Belajar. Yogyakarta: Pustaka Pelajar.

Hakim, Lukman dan Subyantoro. (2018). Learning Writing Explanatory Text Using Group Investigation Models Based on Learning Style.Jurnal Seloka: Jurnal Pendidikan Bahasa dan Sastra Indonesia 7 (3) (2018) : $259-266$.

Kolb, D, A. (1984) Experiential Learning Experience as The Source of Learning and Development. New Jersey: Prentice Hall.

Kosasih, E. (2014). Jenis-Jenis Teks. Analisis Fungsi, Struktur, dan Kaidah serta Langkah Penulisannya. Bandung: Yrama Widya.

Knapp, P dan Megan Watkins. (2005). Genre Text, Grammar: Technologies for Teaching and Assessing Writing. Australia: University of New South Wales Press Ltd.

Kurniawan, Muhammad Ragil. (2017). Analisis Karakter Media Pembelajaran Berdasarkan Gaya Belajar Peserta Didik.JINo P (Jurnal Inovasi Pembelajaran), Volume 3, Nomor 1, Mei 2017 P-ISSN 2443-1591 E-ISSN 24600873.

Kusnida, Faris, dkk. (2015). Keefektifan Penggunaan Media Audio Visual dan Media Komik Strip dalam Pembelajaran Menulis Cerpen yang Bermuatan NilaiNilai Karakter Berdasarkan Gaya Belajar. Jurnal Seloka: Jurnal Pendidikan Bahasa dan Sastra Indonesia 4 (2) ISSN 23016744.

Krisbiono, Agung Dias, dkk. (2015). Keefektifan Penggunaan Model Sinektik dan Model Simulasi dalam Pembelajaran Menulis Teks Drama Berdasarkan Gaya Belajar pada Peserta Didik Kelas XI SMA. Jurnal Seloka: 4 (2) (2015) ISSN 2301-6744.

Moussa, Nahla M.. (2014). The Importance of Learning Styles in Education. Institute for Learning Styles Journal Volume 1, Fall 2014 Page 19 - 27. Diunduh darihttp://www.auburn.edu/academic/e ducation/ilsrj/Journal Volumes/Fall 
Nur Maya Widiyanti et al./Seloka: Jurnal Pendidikan Bahasa dan Sastra Indonesia 9 (3) (2020) : 221 - 229

2014 Vol 1 PDFs/Learning Styles Nahla Moussa.pdf

Olivia, Femi. 2013. Lima Sampai Tujuh Menit Asyik Mind Mapping Kreatif Melatih
Otot-Otot Otak Anak dengan Cara yang Menyenangkan dan Penuh Warna. Jakarta : Elex Media Komputindo. 